1846, April 2-Election held for delegates resulted in selection of Democrats 22 and Whigs 10.

1846, May 4-Convention met and adjourned May 19, remodeling the constitution with boundaries as they are now. Compromise reached with leaders in congress on the boundary question.

1846, Aug. 3-Vote for the constitution 9,492, against the constitution 9,036 . New constitution sent to Washington, congress accepted the changed boundaries, amending the former admission act.

1846, Sept. 9-Governor Clarke issued proclamation announcing that statehood had been attained; called convention to elect state officers and a general assembly.

1846, Oct. 26-Election held; Ansel Briggs, the Democratic candidate, elected governor by a majority of 161 votes over Thomas McKnight, nominated by the Whigs.

1846, Dec. 3-Governor Briggs inaugurated and legislative sessions held in Iowa City.

1846, Dec. 28-President Polk signed bill formally admitting Iowa as a state. The present boundaries of the state had been agreed upon in Iowa and at Washington. The General Assembly had been at work three weeks before the admission date.

1857-New state constitution was enacted after the Constitution of 1844 had been in force eleven years.

\title{
AN INCENTIVE FOR UNSELFISH SERVICE
}

In an address before some 200 delegates to the Iowa Taxpayers association annual meeting in Des Moines, on November 16, 1945, W. R. Boyd, of Cedar Rapids, chairman of the finance committee of the Iowa State Board of Education, told those present that he believed the United States' only chance of remaining a republic lies in a provision for a single six-year term for the president and one giving United States senators a longer term with no re-election. He claims that the only incentive for these officials, under such conditions, would be to make a record for noble, unselfish service to their country.-Ames Tribune. 
Copyright of Annals of Iowa is the property of State of Iowa, by \& through the State Historical Society of Iowa and its content may not be copied or emailed to multiple sites or posted to a listserv without the copyright holder's express written permission. However, users may print, download, or email articles for individual use. 